\title{
Lactic dehydrogenase activity of aqueous humour in retinoblastoma
}

\author{
P. L. R. DIAS, * S. SENTHE SHANMUGANATHAN† AND \\ M. RAJARATNAM†
}

* Department of Physiologv, University of Ceylon, Colombo $†$ Medical Research Institute, Colombo, Ceylon

Lactic dehydrogenase ( $\mathrm{LDH})$ is an enzyme that catalyses the reversible reaction:

$$
\text { Pyruvate + NADH } \rightleftarrows \text { NAD + Lactate }
$$

$\mathrm{NAD}=$ nicotinamide adenine dinucleotide

$\mathrm{NADH}=$ reduced nicotinamide adenine dinucleotide

LDH can also react with NADP.

Although the levels of $\mathrm{LDH}$ have been estimated in the aqueous humour of animals (Kuhlman, and Kaufman, 1960), information regarding LDH levels in human aqueous humour appears to be scanty.

It is known that malignant tumours at different sites in the body are associated with a $\vec{\emptyset}$ increased LDH activity in the corresponding body fluid (Wroblewski, 1957).

The purpose of the present study is to determine whether there is an increased LDE activity in the aqueous humour in cases of intraocular malignancy.

\section{Materials and methods}

Specimens of aqueous humour were collected from fifty patients coming for surgery to the Victoria Memorial Eye Hospital, Colombo. Of these, 46 had non-malignant intraocular disorders and four had retinoblastomata. The non-malignant intraocular disorders included the following:

$\begin{array}{lrll}\text { Cataract } & 33 & \text { Anterior staphyloma } & 3 \\ \text { Adherent leukoma } & 4 & \text { Lens-induced glaucoma } & 2 \\ \text { Aphakia } & 3 & \text { Retinal detachment } & \text { I }\end{array}$

The aqueous humour was collected using an Amsler's needle connected to a dry $2 \mathrm{ml}$. syringe, which was introduced at the limbus. These specimens of aqueous humour and blood were kept at $4^{\circ} \mathrm{C}$ and were analysed within 24 hours of collection.

The LDH activity in both aqueous humour and blood was estimated by the colorimetric method of King (1959). The principle of estimating the enzyme was first described by Wacker, Ulmer, and Vallee (1956), where lactate and NAD are used as substrates and the increase in the optical $\sigma$ density at $340 \mathrm{~m} \mu$ is measured. The advantage of this technique is that the reagents are stable and $N$ cheap.

A unit of activity is the amount of $\mathrm{LDH}$ which will reduce $\mathrm{I} \mu$ mole lactate to I $\mu$ mole pyruvate in I 5 minutes at $37^{\circ} \mathrm{C}$. Activity is expressed in units per $100 \mathrm{ml}$. of specimen.

The volume of aqueous required for the estimation is only $0 \cdot 1 \mathrm{ml}$. and sufficient aqueous humour was obtained even from patients with a shallow anterior chamber. Care was taken to see that $\stackrel{\oplus}{\rightarrow}$ none of these specimens was contaminated with blood. 


\section{Results}

The LDH activity in the aqueous humour of the 46 non-malignant cases varied from o to 350 units/100 $\mathrm{ml}$. (Table I).

Table I LDH Activity in 46 patients with non-malignant intraocular disorders

\begin{tabular}{|c|c|c|c|}
\hline \multirow[t]{2}{*}{ Diagnosis } & \multirow{2}{*}{$\begin{array}{l}\text { Number of } \\
\text { patients }\end{array}$} & \multicolumn{2}{|c|}{$\begin{array}{l}\text { Range of } L D H \text { activity } \\
\text { (units/ } 100 \mathrm{ml} . \text { ) }\end{array}$} \\
\hline & & Serum & Aqueous humour \\
\hline Cataract & 33 & 230 to 470 & Nil to $35^{\circ}$ \\
\hline Adherent leucoma & 4 & I 50 to 240 & $\mathrm{Nil}$ to $\mathrm{I} 60$ \\
\hline Aphakia & 3 & 160 to 480 & Nil to 80 \\
\hline Anterior staphyloma & 3 & 400 to 420 & 40 to 160 \\
\hline Lens-induced glaucoma & 2 & 250 and 400 & 240 and 190 \\
\hline Retinal detachment & $\mathbf{I}$ & 160 & 180 \\
\hline
\end{tabular}

The LDH activity in the serum collected and estimated simultaneously varied between 150 and 470 units/100 ml. The normal range is 160 to 400 units/100 ml. (King, 1959).

The four cases of retinoblastoma investigated gave the results shown in Table II. They all had a white mass behind the pupil which was clinically diagnosed as a retinoblastoma. Subsequent microscopic examination confirmed the diagnosis in all of them.

Table II LDH Activity in 4 cases of retinoblastoma

\begin{tabular}{|c|c|c|c|}
\hline \multirow{2}{*}{ Age (yrs) } & \multirow{2}{*}{ Sex } & \multicolumn{2}{|c|}{ LDH Activity (units/100 ml.) } \\
\hline & & Serum & Aqueous humour \\
\hline $1 \frac{1}{4}$ & $\mathbf{M}$ & 380 & 3,250 \\
\hline $2 \frac{1}{2}$ & $\mathbf{M}$ & 380 & 1,800 \\
\hline 3 & $\mathbf{F}$ & 280 & 2,100 \\
\hline 3 & $\mathbf{M}$ & 480 & 2,660 \\
\hline
\end{tabular}

\section{Discussion}

Since it was not possible to estimate the $\mathrm{LDH}$ levels in the aqueous humour of normal human eyes, these were estimated in the above 46 patients with non-malignant intraocular disorders.

The highest value obtained was 350 units/ $100 \mathrm{ml}$. in a patient with a cataract who had a pseudoexfoliation of the lens capsule. The lowest value obtained from a case of retinoblastoma was more than six times this value.

These results indicate that retinoblastomata are probably associated with a gross elevation of $\mathrm{LDH}$ activity in the aqueous humour.

Non-malignant growths are not associated with increased LDH activity (Erickson and Morales, r96r). The LDH activity in the body fluid bathing a non-neoplastic lesion in a 
patient is lower than the $\mathrm{LDH}$ activity in the serum of that patient (Wroblewski, 1957). Disorders such as primary hyperplastic vitreous and intraocular tuberculosis, which may simulate a retinoblastoma, are therefore unlikely to be associated with gross elevations of $\mathrm{LDH}$ activity in the aqueous humour. It would seem, therefore, that the estimation of the LDH activity in the aqueous humour might be of value in the diagnosis of retinoblastoma.

\section{Summary}

$\mathrm{LDH}$ activity in the aqueous humour of 46 patients with non-malignant intraocular disorders ranged from o to 350 units/ $100 \mathrm{ml}$.

The four cases of retinoblastoma studied gave values of $1800,2100,1600$, and 3250 units/loo ml.

Since LDH activity in the aqueous humour is greatly elevated in retinoblastoma, it seems likely that the estimation of $\mathrm{LDH}$ activity in the aqueous humour may be of value in the diagnosis of intraocular malignancy.

We wish to thank Dr. I. Sri Skandarajah Sivayoham, Dr. U. Athureliya, and Dr. E. Sivalingam of the Eye Hospital, Colombo, for their willing co-operation; Dr. P. Sivasubramaniam for his helpful advice and criticism; and Mr. S. A. N. Perera of the Department of Physiology, University of Ceylon, Colombo, for technical assistance.

\section{References}

ANTEBI, R., and KING, J. (1958) Lancet, I, I 133

ERICKSON, R. J., and MORALES, D. R. (1961) New Engl. F. Med., 265, 531

KING, J. (1958) 7. med. Lab. Tech., 15, 17

- (1959) Ibid., 16, 265

Kuhlman, R. E., and Kaufman, H. E. (1960) A.M.A. Arch. Ophthal., 63, 4 I

WACKer, W. E. C., Ulmer, D. D., and VAlleE, B. L. (1956) New Engl. F. Med., 255, 449

WROBLEWSKI, F. (1957) Amer. F. med. Sci., 234, 30 I 